\title{
The Trade and Mestizo Culture Effect in Ternate
}

\author{
M. Ridha Ajam, Irfan Ahmad \\ Facultas of Humanities, Khairun University, Ternate, North Maluku, Indonesia \\ Email: ajammridha@gmail.com, irfan.ahmad@unkhair.ac.id
}

\section{ARTICLE INFO ABSTRACT}

Received: 08-01-2022

Revision: 13-01-2022

Received : 19-01-2022

Keywords:

Trade; cloves; ternate; culture;

mestizo

This study discusses the spice (clove) trade in Ternate in the XV-XVII centuries by Arab, Chinese, Malay, Javanese, Makassar, Portuguese, Spanish, Dutch and English traders. The importance of clove commodities in Ternate in trading activities makes Ternate one of the international trade networks. This research uses the method of historical science and the study of multiculturalism. The research location is in Ternate City, North Maluku Province. The results showed that Ternate played an essential role in trading activities as a maritime kingdom. The spice route is not just a commodity trading route but also a commercial process that allows the exchange of values and cultures that have helped shape the identity of the Ternate community today. The impact of culture can be found in language, clothing, art, food, and settlements. In other words, the clove trade involving various nations in Ternate also brought together cultures.

\section{Introduction}

Writing the history of trade in the period of the XV-XVII centuries is one of the most common themes. The European historian who can be called a pioneer is J.C. van Leur (1967), M.A.P. Meilink-Roelofsz (1962), and Indonesian historian A.B. Lapan (2009). However, its scope is only limited to a few areas, especially the islands of Java and Sulawesi. This certainly creates a balance in the history of Indonesia itself, which is a very complex area. Various kinds of people and cultures actually bring out the uniqueness of each region. Therefore, this paper will choose the Trade and Cultural Influence of the Mestizo in the eastern part of Indonesia (Ternate) which is very rarely discussed in Indonesian history.

Since ancient times, Ternate has been a stopover and meeting place for ethnic groups from various parts of the archipelago. This has influenced the growth of the City of Ternate, both in the pre-colonial, colonial, until present time. In addition, Ternate also has an essential meaning for foreign nations who have visited this area. As a trading city, Ternate is growing rapidly as an urban center. The inhabitants are not only from the surrounding islands, but also come from various countries. Some of the traders who came to Ternate stayed there while trading or waiting for a good wind season to return to the hometowns.

Trade is one of the determinants of cultural diversity in Ternate. Such as the diversity of dress styles among the sultan, the sultan's family, the nobility, and the people of Ternate. This cultural diversity is a valuable asset. Whether we realize it or not, its existence cannot be separated from a long history starting with the arrival of merchants from Arab, Javanese, Malay, Portuguese to Dutch (VOC), including the reign of the Dutch East Indies.

Departing from the three major works above, it seems that they have been neglected or have not received full attention from Indonesian historians. Therefore, the main purpose of this paper is to see the existence of the port of Ternate, a small town

$\begin{array}{ll}\text { How To Cite: } & \text { Ajam, M. R., \& Irfan Ahmad (2022) The Trade and Mestizo Culture Effect in Ternate. Journal of } \\ & \text { Social Science. 3(1). https://doi.org/10.46799/jss.v3i1.278 } \\ \text { E-Issn: } & 2721-5202 \\ \text { Published By: } & \text { Ridwan Institut }\end{array}$


that thrives on the spice (clove) trade. One of the questions that often arises is how Ternate played a role in trade, which then triggered Arab, Chinese, Malay, Javanese, Makassarese, Portuguese, Spanish, and English traders to come one after another. So that there was an exchange of European culture or known as the Mestizo culture in the scope (sultanate) of Ternate.

The spice trade has influenced the social and cultural life of the people of Ternate. In many ways, these various influences can be seen in the attitudes and behavior of the people of Ternate. The culture of the people of Ternate today is the result of interaction with the cultures of various societies in the past. The traders who came to Ternate carried out mere trading activities and brought the culture of their place of origin. The evidence of this process is reflected in the remains, both physical and non-physical, which represent historical and cultural processes.

\section{Method}

This research is qualitative research that uses a historical approach or Historical Research. Historical research is a systematic investigation of documents and other sources that contain facts about historians' questions in the past (Djamal, 2015). Historical research is a process of critical investigation of past events to produce accurate and correct descriptions and interpretations of these events (Djamal, 2015).

Historical research seeks to reconstruct facts in the past about what, who, when, where, and how objectively, systematically, and accurately carried out at present. The reconstruction process was carried out based on field notes, artifacts and verbal reports of historical actors or witnesses.

\section{Results And Discussion}

\section{Ternate Communities Life: Across Cultures, Languages, and Lifestyles}

Cloves have become a trade product for the people of Ternate and are open to anyone. Trade in the long term has involved many traders from various nations in Ternate. Trading activities in Ternate indirectly shape the composition of the population of the island of Ternate.

At the end of the nineteenth century, Dutch colonialism in the Dutch East Indies positively or negatively impacted the postcolonial state and its identities.Western civilizations naturally entered the lives of indigenous people through cultural contacts (Tickell, Paul, 2008). The process of assimilation of Western culture gave birth to a new identity in indigenous peoples. The impact of the interaction between the natives and the colonizers is the imitation of the lifestyle and culture of the country invaders. In addition, the social system at that time was classified absolutely by the Dutch government, including the aristocratic class as the leading class that the colonizers approached. The sight that was striking and in the spotlight was the aristocratic group for openly imitating the Dutch colonial's oral and written mindset, behavior, and lifestyle. An imitation is a form of the primary social status of an indigenous person and his lifestyle because of the interaction of Eastern and Western cultures. It is not surprising to find various European life styles, such as language, dress, eating manners, etc. in the Ternate community.

\section{a) Language}

Maluku (North) has 32 local languages. Ternate language is one of these languages. The assimilation of Arabic, Malay, Portuguese, and Dutch with local languages has taken place in Ternate. The influence of the languages of these various nations coincided with the increasing spice trade in Ternate.

In addition to the influence of Arabic, there is also Malay which is used as a liaison language for commerce. The Malay language became prestigious and essential in trade. This is evidenced by Kolano Kamalu's mastery of the Malay language (1377-1432) to communicate with merchants from Java. He even married a woman of Malay origin. Even 
the previous sultans of Ternate were very fluent in Arabic and Malay (Van Fraassen, Ch. F. (1987). Sultan Khairun had written letters to the Portuguese governor using Arabic with the Malay spelling on several occasions (Valentijn, 1724).

Malay is necessary as the language of instruction in communication with the indigenous population (Lombard, 2008) because, in Maluku, many ethnic groups use local languages to communicate between them. Almost every resident on this island uses the regional language then create missunderstanding between each other in one ethnic group. Francois Valentijn, a priest who served in Ambon (1685-1695 and 17071713), expressed his views on the Malay language (Ohorella, G. A. 1997) means:

"Malay is used as the language of communication and is used throughout the Indies. People who speak Malay will avoid difficulties since this language is known to almost all aristocratic groups. Meanwhile, those who cannot speak this language will be considered as Easterners who lack education. Malay is beautiful, attractive, and has a very melodious sound." (Groeneboer \& Augusdin, 1995) (Mahayana, 2009).

Traders and missionaries preferred to learn Malay as a lingua franca widely known in various parts of the archipelago (Kridalaksana, Harimurti et al. 1991). The Portuguese, who were the first Europeans to arrive in Ternate, brought a lot of vocabulary and terms and were introduced to the nobility and people of Ternate. The Portuguese were not only powerful politically but also culturally. For instance, according to R.Z. Leirissa (1999), the Malay language was used by the Dutch (VOC) to communicate with the sultan, this shows (Leirissa, 1999) how important the Malay language is for traders, the sultanate, and the people involved in buying and selling activities. Malay was used to writing "Hikayat Ternate" until the nineteenth century.

However, the Ternate language is not pushed or abandoned completely. Such as found in the writing of the saga by Naidah. Over time, and driven by the growing importance of using the Malay language, since the nineteenth century, manuscripts written in Ternate began to be translated by P. van der Crab (Resident of Ternate 18631864) into Dutch-Malay. This article was published in 1878 in Bijdragen tot de TaalLand en Volkenkunde van Nederlandsch Indie (BKI).

\section{b) Lifestyles}

The lifestyles of the Ternate people that was influenced by the spice trade activities in the past is the style of dress. As a results of trade and the introduction of Islam and Christianity in the archipelago, the way local people dress changed. Similarly, the accessories used, such as necklaces. The Maluku region is an important place or market in the early days of clothing export expansion. Means the history of dress in the archipelago reveals a European (Christian) influence (Reid, 1992). Traders also introduced the culture of dressing in an Islamic manner from Java and Malay (Lombard, 2008). However, among Muslims, the culture of dressing in Islamic characteristics; robes, is only seen in the Bobato of the hereafter and the imams of the mosque with the equipment (Reid, 1992).

Based on the records of Tome Pires (1512-1515), since early sixteenth-centuriest traders from Java and Malay came with rough weaving and fine cloth intended as clothing for the king, royal family, and nobles. This proves how much attention is paid to lifestyle, especially appearance (dressing) and using gold jewelry, as used by the Sultan of Ternate, Baabullah (1570-1583) (Lapian, 2008). In a meeting between Baabullah and Francis Drake, Baabullah wore a robe (a long dress commonly worn by Arabs) decorated with luxurious gold thread, ring jewelry, and a sizeable pure gold necklace (Hanna, Willard A. \& Des Alwi (1996). In addition to Baabullah, the apparatus Ternate custom also wears clothing that Islam characterizes 
(robes) with a head covering (turban) (Bawlf, 2003).

The nobles of Ternate were very fond of dressing luxuriously. Clothing is obtained by bartering using cloves. From the clothes, it appears that religion (Islam and Christianity) and modernity became an essential part of The nobles lives. These clothes are used on certain occasions and become part of the lifestyle. The robes were used by the sultans and nobles in traditional events procesion. Meanwhile, European-style clothes (shirts and trousers) are taboo and close to Europeans for many people. Only members of the local aristocracy and indigenous people who had embraced Christianity were allowed to imitate European way of life. Clothing shows a breakthrough by showing the difference in the social status of the Maluku people until the nineteenth century (Van Dijk, 2005).

Besides the trading activities, Europeans also introduced religion. In the nineteenth century, or called the Zending century, there was a need to raise the indigenous population to a better level, involved with the process of evangelism (Ahmad, 2014). European-style habits by the natives are always associated with the social status, then gradually became similiar to the Dutch (Leirissa, 1997).

Dressing neatly and leaving ancestral traditions is considered important by the church. The men adjusted the clothes by wearing long pants and long-sleeved shirts like Europeans. While the women were use chilija/kebaya. These clothes became the daily clothes of women (such as queens and princesses of Ternate) and the Mestizos in the capital city of Ternate. This type of clothing was also introduced to the community when it began to embrace Christianity. This type of clothing seems become a general trend for people in the Dutch East Indies since the nineteenth century (Valentijn, 1724).

Another lifestyle that introduced by Europeans are Ternate people way of eating. Europeans introduced the sultans and royal nobles to eat using spoons and forks at banquets. This is reasonable considering the tastes and Europeans eating culture and Ternate people are significantly different due to seasonal influence. Europeans brought the foods to Ternate, then combined with local food to create new food recipes enjoyed by both Europeans and Ternate people. The types of Portuguese cuisine and food found in Ternate, such as bobengka, salad, panada, sour pedis dishes, and achar. Various types of food can be found at the event held by the nobles, Portuguese, Dutch, and the Sultanate of Ternate (Djaafar, 2007). Later, this type of food is also favored by the general public in Ternate or Maluku (North).

\section{c) Art}

Ternate is an essential port in international trade and shipping routes. The influence of other countries that had contact with Ternate is also evidenced by the presence of traces of the arts of music and dance which are evidence of the inclusion of various cultures from various countries, such as Java, Arabia, China, and Europe (Leirissa, 1999).

The influence of Javanese elements in Ternate art, both in the palace and in folk art, can be seen in gamelan, kenong, gong, and fiddle musical instruments. Sultan Zainal Abidin initially brought these musical instruments when he returned from Java (Giri). This musical instrument was used in the Ternate palace to enrich the artistic treasures of the Ternate people. Almost all types of orchestras in Ternate people can be found with these musical instruments. During Sultan Zainal Abidin reign, a typical Ternate gending combined with Java, called the cikamomo, appeared which was played as an instrument (Sularto, 1980).

Islamization of Ternate and Maluku (North) people through art can be seen in the art of iron spurs or debus. Taji Besi is a martial art known as one of the performing arts. The existence of Taji Besi in Ternate is associated with the arrival of Syech Al-Banjari from Kalimantan who came to introduce the 
practice of the tarekat and carry out propaganda against the Dutch colonialists in Tidore. The Taji Besi ritual, or more familiarly called Taji Besi, among the Tidore people, is an Islamic culture that has entered Islam. This is a medium for spreading religion Islam used by preachers in Tidore, Ternate, and Halmahera. In implementing the Taji Besi ritual, the context that cannot be separated from its implementation is tarekat science. The philosophy of the Taji Besi tradition in the Tidore community is that submission to the Creator (Allah SWT) causes them to have the strength to face danger, as symbolized by the sharp and hot objects used in this ritual tradition (Usman, 2010).

Taji besi is done by chanting the prayers of the holy Qur'anic verses while stabbing a pointed iron into the chest. However, Taji besi never hit the chest. This media has its charm, especially when immunity was considered fairly practical selfdefense, especially if there was a war against the Dutch.

Apart from being influenced by Arab culture, some dances in Ternate are also influenced by Portuguese culture. Some of these popular influences can be found at the time of the party, there are: dadansa, donci, katreji, and lenso dances. Some of these Portuguese dances were very popular among the courtiers which were only enjoyed by the aristocrats at that time. Appearances are closed and only held in the palace foyer. Dadansa dance, for instance, was only performed in the palace during the Sultan of Ternate, Mudaffar I (1610-1627), and could only be danced by dancers from Soa Ngare. Dancers for this dance are not allowed from the soa or clan from outside. In fact, the attributes in the form of handkerchiefs (lengso), dancer's clothes and hats (capeo) are very thick with Portuguese culture. Recently, this type of dance has also developed and can be enjoyed by the general public (Djaafar, 2007).

The arts brought by the Portuguese have influenced various forms of art of the
Ternate people. In addition to the several types of dances mentioned above, the Portuguese also introduced musical instruments, such as: violin, triangle, and harmonica, to accompany the dance.

At the time of the trade boom, in the sixteenth century, Ternate had been positioned by Asian traders and then Europe became an important port for the spice trade in the Maluku region (Reid, 2011). Such a situation has caused Ternate has experienced rapid development. The expansion of the territory carried out by the Sultan further emphasized Ternate's position as a trading port. Ternate can provide a sense of comfort for traders who make transactions to purchase cloves and the potential market for the spice trade in the eastern region of the archipelago.

In the nineteenth century, traders from China, Arabia, Malay, Java, and Makassar had trade contacts with the Ternate people. However, the traders did not immediately make settlements to be occupied and named after their origin, as did the Malays in Kampung Melayu. The traders felt it was unsafe to occupy and build villages around the coast because of frequent wars between groups and kingdoms (Ternate-Tidore). Some traders choose to live on the coast quickly, moreover some traders are return to trade.

\section{d) Settlement}

One of the essential things that are often overlooked in Ternate history is how changes occurred in Ternate as an influence arising from contact with traders. The cultural orientation of traditional community settlements in Ternate was influenced through contact with traders. Another impact emerged as the influence of the conversion of the population of Ternate to Islam which was introduced by the ulama from Arabia and Java.

The population of Ternate exhibits excellent variation in small social units, consisting of ethnic groups, such as Chinese, Arabs, Makassarese, and Europeans. Each of ethnic groups occupies personal village. 
Unfortunately, the population of Ternate at that time was not well identified, making it difficult to ascertain. The new population began to be identified when the Ternate Residency was formed. The population has been recorded by the Dutch colonial government since the nineteenth century, although it is still difficult to know certainly because each report differs from one another. The population composition in that period was limited to the citizens of the Sultanate of Ternate, and Tidore as the center of government (Leirissa, 1993).

Until the nineteenth century, the category of government citizens in Ternate was very diverse. In addition to Ternate and non-Ternate people, there are also residents and settlements of traders who have settled. These traders generally inhabit the villages in the city area, especially around the Oranje Fort. They live in groups in villages named after their country of origin. Traders who came from China, lived in groups with fellow Chinese. Likewise other traders, they formed their colonies. Likewise with immigrants or other traders. This continues so that today there are still village names of traders from various countries. Therefore, the settlements in Ternate City can be grouped into four, namely: (1) European settlements, (2) Chinese settlements, (3) Arab settlements (4) Makassar settlements.

The progress of commerce turned out not only to attract traders, but also to trigger the formation of new settlements. Likewise people who build settlements as trading areas. Because of this, the European, Chinese, Arab and Makassar ethnic settlement complexes are considered very strategic. Their settlement is by the main activity of life as a trader. They live in areas close to ports and markets. The development of the city of Ternate tended to the north after the Fort Oranje was built and the free competing port was reactivated.

\section{European Village}

Since the arrival of Europeans on the island of Ternate at the seventeenth century, there has been a new community called the indigenous Christians "Mestizos". It was commonly referred to as "black Europeans". They consist of all indigenous people who are Catholic Christians and their lifestyles tend to follow the cultural patterns of Europeans (Portuguese and Spanish). Orang "Mestizos" is the name given by Malays to Portuguese Christians who speak or communicate in Malay (Andaya, 1993); Wallace, A. R. (1871).

In general, the "Mestizos" inhabit the area around the Portuguese and Spanish forts in Ternate and Tidore. When the Portuguese forts in Ternate and Tidore fell to the Dutch in 1605, the Dutch sent the "Mestizos" (indigenous Christians) along with the Portuguese to Manila. They returned to the Moluccas in 1606 together with the Spaniards (Fraassen, 1987) and settled in the area of "Gam-La-Mo." Indigenous Christian communities in this category include all "Mestizos", Mardica, Inlandse Cristenen, and the Pampangans.

After the VOC occupied the fort of Oranje, the Dutch had found indigenous people who were Christians. Since the nineteenth century, the Dutch colonial government and the military proved capable of being at the forefront of colonial rule in various services. The indigenous Christian population was placed exclusively and directly under the government's government. In the nineteenth century, they were the last representation of the category of government citizens that appeared in the population grouping under the name 'inlandse christenen' or referred to as black European mestiezen (mestizos) (Ahmad, 2014).

Mestizos or black Europeans, includes all indigenous Christians including various Ternate nobles whose conversion to Christianity and culture follows the pattern of the metizos culture. Indigenous Christians living around the fort of Oranje (Andaya, 1993). Since the increase in the number of 
Europeans is difficult to ascertain, the regulation "Kitab UU" 1861 No. 142 stipulates that registration of population numbers for indigenous Christians begins without damaging their registration rights in the registry book. In registration, the label "Indigenous Christian" must be included after their name, because the name alone is not enough to distinguish them from EuropeanChristians. On the other hand, there is an opinion that the label prohibited because it is not included in the Act (Clarkq, FSA de, 1890).

The existence of the Dutch in Ternate, which continued to increase in the XIX-XX centuries, seemed to make its characteristics. The former settlement of the Mestizos west of the fort of Oranje became a European village. European villages were usually occupied by soldiers and employees who came from the Netherlands. However, the Moluccans call the village a Sarani (Christian) village or Fala Sarani. When Wallace arrived in Ternate, he mentioned that a European/Dutch Christian village was located around Orange Fort. Fala Sarani is a special designation for residents of European descent who are adjacent to the village of Santiong (Wallace, 1871).

Over time, the Dutch also married indigenous women, or vice versa. Indigenous people who converted to Christianity inhabited the area south of the fort adjacent to the Protestant Church-at the site of this church, the Benteng cinema, and the Selekta shop were later built. The placement of indigenous Christians in the area was intended to distinguish European Christians from indigenous Christians.

Fraassen (1987) writes that indigenous Christians mostly live in Sarani or Christian villages. There is also a Protestant church in this village. They were employed as Dutch soldiers or in the service of European-owned companies in the Orange fort. Until the middle of the nineteenth century, indigenous Christians, or so-called "black Europeans", including all indigenous Christians (Van Fraassen, 1987). Their custom at Christmas and New Years is to dress neatly, are very fond of music festivals, dance, and like alcoholic drinks (Wallace, 1871).

\section{Chinese Village}

The high demand of cloves made many traders from China went to Maluku by using Jung. They come to buy cloves and trade them in other places (Robin A, 2003). In fact, in historical records, it is known that Chinese merchants had discovered Maluku during the T'ang Dynasty (618-906) (Abdurachman, 2008). Therefore, the mention of Maluku by Chinese merchants varied greatly from era to age. Among the various the kinds of mentions are: Ma-li-ku, (618-906), Mi-li-ki (1300-1368), Wonugu (1225), (1304), Wenlugu, Dinxiang, Mawu zhou, (1339), and Wenlaogu. The mention of Maluku and the road to the spice islands was kept secret by the merchants at that time because it was closely related to the very expensive price of cloves (Hamid, 2013).

The arrival of the Chinese to Maluku that time was only for trading purposes. After the buying and selling activities, they returned to sailing away from Maluku. Although in the XVI-XVII centuries some of the Chinese had been in Ternate, however, there was no permanent special settlement for the Chinese at that time. This was caused by the "Chinese rebellion" in Batavia in 1740. At that time, most Chinese were banned from trading by the VOC and eventually arrived in Ternate. Thus, the number of data of the Chinese in Ternate in the seventeenth century is tough to know. In addition, they live scattered around Talangame Harbor, Bastiong, and around the Oranje Fort.

Chinese and Arabs began to come to Ternate in large groups in 1822. At that time, the Sultan of Palembang, Mahmud Badaruddin, was serving his sentence of exile in Ternate (Amal, 2016). In the Chinese group at that time, there were 5 ( five) Chinese clans that still survive today, namely 1) Tjan Hoat Seng; 2) Tjan Tjok Seng; 3) Tjan Eng Hong; 4) Tjan Ban Seng; and 5) Tjan Tjai Lo (Jafar, 2005). 
In 1854, many Chinese and Arabs came to carry out trading activities and settled in Ternate and the Ternate Krasidenan area, Halmahera island and its surroundings. At that time, the port of Ternate was opened for trade using steamboats. Most of the Chinese who came to Ternate did not bring their wives, and some were not married. Over time, the Chinese living in Ternate married natives and embraced Islam, such as the Tjan Hoat Seng clan.

After the number of Chinese people increased since the 1850s, they formed a permanent settlement in the southern part of the Oranje fort. As stated by de Clercq (1890) in his annual report, when he was Resident in Ternate, he wrote: "in the southern part of the Oranje fort, there is a Chinese village bordering the Palembang village, and in the west it is bordering the Mestizos village, Europe or known as the village of Mestizos. Sarani village (Wallace, AR 1871).

In 1870 , the Sultan of Ternate legally gave the Chinese a contract to trade in Ternate. The Sultan gave and appointed a Jogugu of the Ternate Sultanate of Chinese ethnicity named Loem Seng. The awarding of this title was based on the consideration that the Chinese did not only exist in Ternate, but were spread all over the Moluccas. Therefore, this title could bind the Chinese at that time with the Sultanate of Ternate politically and economically. In fact, Chinese people with the surname Tjan were integrated as part of Soa Melayu Cim in Kampung Makasar. In addition, the Chinese are also part of the Soa Lima Tahu, from the Liem Seng clan (Jafar, 2005).

After the Ternate Sultan gave a legal contract to inhabit Ternate and its surroundings, the number of Chinese continued to increase. The Chinese who have long inhabited Ternate have two adjacent villages. First, the Chinese who embraced Islam occupied the Kampung Makasar around the Lae Cim Mosque (currently the An-Nur Mosque). Second, the Chinese who adhere to the Confucian religion and maintain the Chinese New Year celebrations make settlements called Kampung Cina. There is a place of prayer/pagoda in the village for them (Clarkq, F.S.A. de (1890).

Wallace (1870) argues the Chinese houses in Ternate were made entirely of stone, which were arranged and then glued together using "kalero". The roof of their house is arranged very tightly using thatch leaves (katu). As a result, when there was an earthquake (earthquake), their houses were severely damaged (Wallace, A.R 1871).

During that period, in Kampung Cina there was a main road with a number of lanes (small roads) connecting one road to another. The village has a population of 500 Chinese people. In addition to the Jogugu title which was given by the sultan, the Chinese also received 2 (two) other honorary degrees for loyal to the sultan, there are: a captain and a lieutenant to help run the government. Even though the Chinese got a strategic space and position in the sultanate of Ternate, they remained on the main goal, namely trading (Clarkq, F.S.A. de (1890).

\section{Arab Village}

Arab has been arrived in Ternate since long time. Maluku is often associated with Arabic to indicate its territory as the AlMamluk Peninsula, although the reason why these words were associated with Maluku still unknown. However, the transcription of the word Al-Mamluk has been written in several media such as: the flag of the Sultanate of Ternate which uses Arabic, the administration of the kingdom, and the names of the sultans of Ternate. Although the arrival of the Arabs has been going on for a long time, in Maluku historical sources the information about the settlement of Arabs still missing, either specifically in Ternate or in general in Maluku. As is known, the arrival of Arabs in Ternate was initially only for trade purposes and to spread Islam. Therefore, they did not stay in one place but moved from one island or region to another (Jafar, A. I (1990). After the Oranje fort was made the headquarters of the VOC, Valentijn (1724) noted that apart from the Dutch, on the island of Ternate 
there were also Malays, Makasars, Chinese, Arabs and Javanese. Their existence was due to the clove trade (Clarkq, FSA de (1890). However, Valentijn did not mention the location of the Arab settlements at that time. The first reports of Arabs in Ternate It was only recorded in 1822 at the same time as the Sultan of Palembang, Mahmud Badaruddin, who was serving his sentence of exile in Ternate (Amal, 2016). Apart from Palembang people, there were also Arabs and Chinese (Jafar, 1990) oral history and written sources; it is revealed that the Arabs carried out trading fulfillment of their needs in the vicinity of the fort of Oranje. They lived in harmony with Chinese and were documented well into the twentieth century.

Similar to other groups of immigrants, Arabs lived in Ternate and made a settlement called Kampung Arab or called "Kampung Tenga(h)". It was called Tenga(h) village, because the village was in the middle of a settlement surrounded by various villages, such as Kampung Cina, Palembang, and Europe/Sarani.

In a statistical report in 1854,112 Arabs lived in Ternate south of the Oranje fort and around the market. They were considered as the people who have formed the Arab village, or may have been formed long before. However, colonial sources were very hard to come by in this study regarding the Arabs in Ternate. As a result, only some information was obtained from the records of Dutch officials and annual reports (Koloniaal Verslag (KV), 1880).

In 1890, when the village was formed, Sayid Muhsin Bin Muhammad Albaar, known as Habib Muhsin, made the house's terrace a musallah for the five daily congregational prayers. Meanwhile, Friday prayers were held at the Sultan Mosque of Ternate. Over time, when more and more Arabs and Musallah no longer accommodated the congregation, Habib Alwi Bin Ahkmad Alhadar's idea emerged to find a new location and build a mosque. From the deliberation results, it was decided to buy land belonging to the Sultan of Ternate, Arsyad, in the southern part of the Oranje fort. The place is considered strategic and the location is very spacious. The land sale and purchase agreement between Sultan Arsyad Sayid Muhsin Bin Muhammad Albaar was carried out with a land area of $3246 \mathrm{m2}$. At the initiative of Sultan Arsyad, the price of the land was only paid in half, while the rest was used to build a mosque. After the sale and purchase were carried out, the former residence of Sultan Arsyad was turned into a mosque, which was named Masjid Al-Habib, which means "beloved mosque". However, some people in Ternate at that time called it the "Arabic Mosque" (Assagaf, 2001).

Arabs in Ternate also have coconut plantations and grow various other crops. They obtained land by buying from the sultan, the sultan's children, or nobleman. They also gain respect from most of the people of Ternate for religious reasons. Some Arabs became religious teachers. In the past, the Sultan of Ternate invited several people with Arab nobility. Some of them follow the title Sayid, meaning descendants of the Prophet Muhammad. They also had a significant influence in the Sultanate of Ternate (Van Fraassen, 1987).

Over time, Arabs married local women. They married women of prominent lineage. However, the Arabs in Ternate tend to be secretive in maintaining the purity of their kinship. In marriage, for example, they are more likely to be endogamous (taking partners from among themselves, fellow Arabs) than exogamous (taking partners from outside their circle, not Arabs). This affects the population of Arab descent in Ternate which seems to be growing slowly.

\section{Makassar Village}

Kampung Makasar is located just north of the fort of Oranje. This area is a residential area for residents who are immigrants from the south of Sulawesi. They are government residents who are Muslim. The Makassarese settlements in Ternate were formed in the same way as the Makassar settlements in 
Ambon also in the XVII to XVIII centuries. According to Rumphius, the Makassarese in Ambon were brought by the Dutch. After the end of the Ambon war (1656), prisoners of war consisting of Makasarese in Ambon were released. They were then chosen to remain in Ambon or return to their ancestral lands (Rumphius \& Manusama, 1983).

The origin of the existence of the Makassarese in Ternate took place after the "Makassar War" in 1667-1669. Admiral Speelman at that time, in alliance with Aru Palaka (Kingdom of Bone) and Sultan Mandar Syah (Kingdom of Ternate), defeated the power of the Makassar Kingdom. At the start of the war, January 1667, Speelman took 5,500 Makassarese to Buton as prisoners of war. Speelman then took the prisoners of war to Ternate and placed them in the vicinity of the Oranje fort (Van Fraassen, 1987). Makassar people have been in Ternate long before in doing trade. However, in the century. XV, or long before, did not inhabit a particular area or named it Kampung Makasar.

According to Naidah, the so-called Makasar people in Ternate were prisoners of war from expeditionary voyages in South Sulawesi. Those caught were handed over to the VOC (Van Dick 1878). From the beginning, there were independent Makasarese people from the village of Makassar, while not for Muslim Makasarese who were citizens of the VOC, who had arrived in Ternate and moved to live in In the second half of the seventeenth century, the VOC had reinforcements from the Makasarese in several areas, including Batavia (Van Fraassen, Ch. F (1987). In the daghregister (diary) of 1665 , there were as many as 120 men as reinforcements.

The first reports about Makassarese in Ternate were recorded in 1681 . At that time, there were approximately 70 Makasarese living in Ternate. A total of 32 of them are men. In the late seventeenth and early seventeenth centuries, the Makassarese in Ternate were Muslims from South Sulawesi.
They naturally cannot have marriage relations with mardjikers or mestizos given their religious background. Thus, the Makassarese in Ternate is grouped as Muslim government residents and inhabit the Makasar village.

In the nineteenth century, Makassarese were employed in the Dutch colonial defense sector. Their leader bears the title Kapita Makassar or 'Captain Makassar' by the Gouvernement Government. Apart from Kapita Makassar, Makassarese also gets jobs as Malay writer or 'Malay writers' who actively work in the resident's office. In the past, Kampung Makassar had a mosque. However, the Sultan of Ternate still has a strong influence on religion in this village. Likewise, the position of judge or judge of the Makassar village Syria.

In conducting population data collection in the government area of Ternate in the nineteenth century, the Dutch colonial government often combined Chinese Muslims and Makassarese. They are categorized as Arabs and are occasionally referred to or recorded as Makassarese. This makes the number of people in the Makassar category more significant. The Muslim government residents for the Makassar category show good fluctuations in the XIX century. In the period 1836-1871, the number of Makassar people in Ternate reached 23,111 people. The average number of residents of the 27 records in $1829-1885$ is 1,338 inhabitants.

\section{Conclusion}

The spice trade is an international trade chain. This activity connects one area to another. Traders (merchants) stop at the port, from one country to another, to look for or trade their wares. The archipelago is a place of crossing and stopover in this trade traffic. Movement/movement of people, communities, and merchant ships from various directions crossing the waters of the archipelago to trade, whether obtained through buying and selling or bartering, with Nusantara spices. 
In the context of the spice trade in Maluku in the XIV-XIX centuries, Ternate emerged as a port city. Clove, as one of the important spices, was a trade commodity that was loved by many merchants and nations at that time. Ternate is blessed with the highest quality clove plants. Supported by adequate port facilities, more and more traders come to Ternate. They set up trading posts in Ternate. In fact, many of them ended up living and settling in Ternate. Of course, their trading activity remains their main job.

Ternate has had power in the trade sector for a long time, long before the arrival of Europeans in Maluku. Political power and trade networks have been formed in relation to other nations. The trade chain of the past has placed spices as the main commodity since the beginning of $A D$ with contacts between Indonesian traders and Chinese, Arab, Indian and Malay traders. Clove which is located in Ternate is one of the most valuable spices, the scarcity factor and a high level of difficulty to find between producing areas to consumer areas in Europe, making clove prices very expensive.

The exploration to find the origin of the clove plant became the embryo of the birth of imperialism and European colonialism. Among European nations, the Portuguese and Spanish were more enthusiastic than other Europeans in finding clove producers. This spice trading network became more and more crowded. The Maluku Islands, especially Ternate, were visited by Europeans around the sixteenth century for the purpose of finding and trading spices. This is marked by the control over Ternate as one of the important ports in the trade network in the archipelago. The Portuguese and Spanish in the context of global trade, are the two nations that most determine the establishment of the spice trade network. The network is: the western world as a consumer and the eastern world as a commodity producer.

The spice trade in Ternate has brought together traders from various parts of the world, such as the Chinese, Arabs, Persians, Malays, Makassarese, Portuguese, Spanish, Dutch and English. Trading activities form cultural contacts (cultural interactions) that are intensive and cover a wide geographical space. Cultural contacts that occurred through inter-island and intercontinental shipping and trade, gave rise to cultural assimilation and acculturation that gave a variety of cultural patterns in Ternate that still survive to this day. This shows that this spice trade correlation involves many related parties.

The importance of spices has shown us historical evidence that one of the things that triggered the development of shipping and trade was the main commodity from Ternate, namely cloves. The traces of the triumph of the clove trade have left a shipping lane known as the "Spice Route". This wide shipping lane connects the archipelago with various regions and countries on other continents. This spice route is the node of civilization and the pride of the Indonesian nation's cultural heritage.

\section{References}

Abdurachman, Paramita Rahayu. (2008). Bunga angin Portugis di Nusantara: jejak-jejak kebudayaan Portugis di Indonesia. Yayasan Obor Indonesia. Google Scholar

Ahmad, Irfan. (2014). Agama Sebagai Perubahan Sosial: Kristenisasi di Tobelo 1866-1942. Lembaran Sejarah, 11(1), 83-98. Google Scholar

Amal, M. Adnan. (2016). Kepulauan rempahrempah. Kepustakaan Populer Gramedia. Google Scholar

Andaya, Leonard Y. (1993). The world of Maluku: Eastern Indonesia in the early modern period. University of Hawaii Press. Google Scholar

Assagaf, M (2001). "Riwayat Masjid Muttaqien Ternate". Buletin Pancona. Volume 1, Nomor 2. Edisi: 27 Agustus-15 September. Ternate, Lembaga 
Pengkajian dan Pengembangan AlKhairaat-LP2A.

Bawlf, Samuel. (2003). The Secret Voyage of Sir Francis Drake: 1577-1580. Bloomsbury Publishing USA. Google Scholar

Djaafar, Irza Arnyta. (2007). Jejak Portugis di Maluku Utara. Ombak. Google Scholar

Djamal, Muhammad. (2015). Paradigma penelitian kualitatif. Yogyakarta: Pustaka Pelajar. Google Scholar

Fraassen, Ch F. van. (1987). Ternate, de Molukken en de Indonesische archipel. Leiden: Leiden University. Google Scholar

Groeneboer, Cornelis Roelof, \& Augusdin, Jessy. (1995). Jalan ke barat: Bahasa Belanda di Hindia-Belanda, 1600-1950: sejarah politik bahasa. Erasmus Taalcentrum. Google Scholar

Hamid, Abd. Rahman. (2013). Sejarah Maritim Indonesia. Penerbit Ombak. Google Scholar

Jafar, A. I (1990). "Pembaruan Masyarakat Cina di Ternate". Skripsi: Pendidikan Ilmu Sejarah, IKIP Manadao.

Kridalaksana, Harimurti ed al. (1991) Masa Lampau Bahasa Indonesia: Sebuah Bunga Rampai. Yogyakarta: Kanisius.

Lapian, Adrian B. (2008). Pelayaran dan perniagaan Nusantara abad ke-16 dan 17. Komunitas Bambu. Google Scholar

Leirissa, R.Z (1993) Sejarah Kebudayaan Maluku. Jakarta: Departeman Pendidikan dan Kebudayaan. Google Scholar

Lombard, Denys. (2008). Nusa Jawa: silang budaya bagian III: warisan Kerajaankerajaan konsentris. Jakarta: PT Gramedia Pustaka Utama. Google Scholar

Mahayana, S. (2009). Perkembangan Bahasa
Indonesia-Melayu di Indonesia dalam konteks sistem pendidikan. INSANIA: Jurnal Pemikiran Alternatif Kependidikan, 14(3), 395-424. Google Scholar

Ohorella, G. A. (1997) Ternate Sebagai Bandar di Jalur Sutra; Kumpulan Makala Diskusi. Jakarta: Departeman Pendidikan dan Kebudayaan.

Reid, Anthony. (1992). Asia Tenggara dalam Kurun Niaga 1450-1680 Jilid 1: Tanah di Bawah Angin (Vol. 1). Yayasan Pustaka Obor Indonesia. Google Scholar

Rumphius, Georg Everard, \& Manusama, Zacharias Jozef. (1983). Ambonsche landbeschrijving. Arsip Nasional Republik Indonesia. Google Scholar

Sularto, B. (1980) Sekitar Tradisi Ternate. Jakarta: Departemen Pendidikan dan Kebudayaan. Google Scholar

Tickell, Paul. (2008). "Cinta di Masa Kolonialisme: Ras dan Percintaan dalam Sebuah Novel Indonesia Awal. Dalam Sastra Indonesia Modern Kritik Postkolonial (Penyunting Keith Foulcher dan Tony Day). Jakarta: Yayasan Obor Indonesia dan KITLV. Google Scholar

Usman, Tauhid (2010) "Taji Besi (Dabus): Ritual dan Syiar Islam di Tidore Tahun 1965 - 1999". Tesis; Univeritas Gadjah Mada.

Valentijn, F. (1724). Uitvoerige Beschryving der vyf Moluccos. Dordrecht: Joannes van Braam Boekverkopen.

Van Fraassen, Ch. F. (1987) "Ternate, De Molukken en De Indonesische Archipel, Van Soa Organisatie en Vierdeling: Een Studie van Traditionele Samenleving en Cultuur en Indonesia, Deel II". Disertasi Universiteit Leiden. Google Scholar

Van Dijk, Kees. (2005). Sarung, Jubah, dan Celana: Penampilan sebagai sarana pembedaan dan diskriminasi. Outward Appeareances: Trend, Identitas Dan Kepentingan (Pp. 57â€"120). Yogyakarta: LKiS. Google Scholar 
M. Ridha Ajam, Irfan Ahmad

Wallace, Alfred Russel. (1871). Insulinde: het paradijsvogel (Vol. 2). PN van Kampen. land van den orang-oetan en den

\section{Copyright holder :}

M. Ridha Ajam, Irfan Ahmad (2022)

First publication right :

Journal of Social Science

This article is licensed under:

(cc)

